\title{
TANGGUNG JAWAB PELAKU USAHA NIKOTIN CAIR YANG KEMASANNYA TIDAK TERCANTUM PERINGATAN KESEHATAN
}

\author{
Khrisna Khristian, Fakultas Hukum Universitas Udayana, e-mail: \\ khristiankhrisna@gmail.com \\ Ida Ayu Sukihana, Fakultas Hukum Universitas Udayana, e-mail: \\ ayu_sukihana@unud.ac.id
}

doi: https://doi.org/10.24843/KS.2020.v08.i12.p03

\begin{abstract}
ABSTRAK
Tujuan penulisan adalah untuk mengetahui perlindungan konsumen rokok elektrik yang tidak tercantum label informasi dan peringatan kesehatan serta tanggung jawab pelaku usaha akibat dari bahaya yang ditimbulkan dari konsumsi rokok elektrik. Dalam penelitian ini digunakan metode penelitian hukum normatif. Hasil dari penelitian adalah nikotin cair dapat dikategorikan sebagai produk tembakau atau HPTL sebagaimana tercantum dalam pasal 1 angka 18 Peraturan Menteri Keuangan Republik Indonesia No. 67/PMK.04/2018 Tentang Perdagangan Barang Kena Cukai Yang Pelunasan Cukainya Dengan Cara Pelekatan Pita Cukai Atau Pembubuhan Tanda Pelunasan Cukai Lainnya. Untuk itu informasi yang dicantumkan didalam kemasan nikotin cair sangat diperlukan dengan tujuan untuk melengkapi hak konsumen dan merupakan bentuk kewajiban dari pelaku usaha sesuai denga pasal 7 huruf b Undangundang nomor 8 tahun 1999 tentang Perlindungan Konsumen.
\end{abstract}

Kata Kunci: Tanggung Jawab, Pelaku Usaha, Nikotin Cair, Label Peringatan Kesehatan

\begin{abstract}
The purpose of writing is to determine the protection of e-cigarette consumers who do not include information labels and health warnings as well as the responsibility of business actors due to the dangers posed by the consumption of e-cigarettes. This research uses normative legal research method. The result of this research is that liquid nicotine can be categorized as a tobacco product or HPTL as stated in article 1 number 18 Regulation of the Minister of Finance of the Republic of Indonesia No. 67 / PMK.04 / 2018 concerning the trade of excisable goods whose excise is paid off by attaching an excise tape or affixing other signs of payment of excise. For this reason, the information contained in the liquid nicotine packaging is very necessary with the aim of completing consumer rights and is a form of obligation of business actors in accordance with article 7 letter b of Law number 8 of 1999 concerning Consumer Protection.
\end{abstract}

Keywords: Responsibility, Business Actors, Liquid nicotine, Health Warning Label

\section{Pendahuluan}

\subsection{Latar Belakang}

Kegiatan merokok bukan lagi dianggap sebagai hal yang melanggar norma terutama dalam kalangan masyarakat Indonesia. Berdasarkan data dari Survei Ekonomi Nasional pada tahun 2014 yang dilakukan oleh Badan Pusat Statistik (BPS), masyarakat mengeluarkan sejumlah sebelas koma empat persen $(11,4 \%)$ untuk mengkonsumsi tembakau dan sirih apabila dibandingkan dengan total pengeluaran kebutuhan pangan 
sehari-hari. ${ }^{1}$ Meskipun lebih banyak efek negatif yang dapat timbul di tubuh manusia sebagai dampak mengkonsumsi rokok, namun tetap saja produk ini digandrungi masyarakat. Hal ini disebabkan oleh efek adiksi atau candu dalam produk tembakau yang mampu menahan konsumer rokok untuk berhenti. ${ }^{2}$ Selain itu terdapat zat nikotin yang memicu efek kesenangan di otak walaupun hanya sementara tetapi efektif membuat rasa ketergantungan terhadap penggunanya. Orang yang telah berada dalam fase candu ini akan merasa mudah marah dan mengalami perubahan suasana hati apabila tidak mendapatkan asupan nikotin dalam satu hari. ${ }^{3}$

Bersamaan dengan perkembangan jaman, masyarakat Indonesia yang telah memiliki ketergantungan maupun yang belum memilih untuk mencoba teknologi baru dalam menggunakan produk tembakau yang lebih dikenal dengan Vape atau Vapor. ${ }^{4}$ Dalam penggunaannya Vape atau Vapor ini memerlukan beberapa alat seperti bagian baterai, bagian atomizer (digunakan untuk menguapkan cairan nikotin) serta bagian nikotin dalam bentuk cairan. Kadar nikotin dalam produk cairan nikotin ini bervariasi walaupun sering kali kadar yang tercantum tidak sesuai dengan kadar yang sebenarnya. ${ }^{5}$ Dalam cairan nikotin ini terdapat beberapa zat yang membahayakan tubuh seperti Karbonil, Tobacco specific nitrosamine, Diethylene glycol, Propileen glikol, dan perisa (flavouring). ${ }^{6}$

Melalui Peraturan Pemerintah Nomor 109 Tahun 2012 Tentang Pengamanan Bahan Yang Mengandung Zat Adiktif Berupa Produk Tembakau Bagi Kesehatan dan Peraturan Menteri Kesehatan Republik Indonesia Nomor 28 Tahun 2013 tentang Pencantuman Peringatan Kesehatan Dan Informasi Kesehatan Pada Kemasan Produk Tembakau terutama dalam Pasal 3, dapat dilihat usaha dari pemerintah pusat untuk memberikan perlindungan kepada konsumen nikotin cair yang meletakkan kewajiban bagi pengimpor produk nikotin cair untuk mencantumkan Peringatan Kesehatan dalam produk hasil tembakaunya. Tetapi tetap saja terdapat beberapa pelaku usaha cairan nikotin tidak mengindahkan peraturan tersebut. Hasil data empirik yang dilakukan oleh APVI (Asosiasi Personal Vaporizer Indonesia) pada tahun 2018 tercatat lebih dari 500 produsen liquid nikotin/nikotin cair, dengan lebih dari 170 distributor atau importir rokok elektrik, 4.000 pengecer nikotin cair/liquid vape, dan 1.1 juta konsumer rokok

1 I Komang W. dan I Nyoman Mudana, "Pelaksanaan Peraturan Daerah Provinsi Bali Nomor 10 Tahun 2011 Tentang Kawasan Tanpa Rokok Dalam Rangka Perlindungan Terhadap Perokok Pasif." Jurnal Hukum Kertha Negara, 02, No. 01, (2014), 3.

2 Hacinka Batan dan Westra I Ketut, "Peredaran Produk Rokok Elektronik Yang Tidak Mencantumkan Label Komposisi Zat Adiktif Dalam Perspektif Hukum Perlindungan Konsumen." Jurnal Hukum Kertha Semaya, 5, No. 1 (2017), 7.

3 Desiyana Vernia dan Sarjana I Made, "Perlindungan Konsumen Terhadap Batasan Kandungan Tar Dan Nikotin Pada Produk Rokok." Jurnal Hukum Kertha Semaya, 7, No. 8, (2019), 8.

4 AM, D. A. S, \& Sutama, I. B. P, “Tanggung Jawab Perusahaan Vapor Juice Inc Bali Terhadap Konsumen Pembeli Rokok Elektrik Jika Terjadi Ledakan Rokok Elektrik." Jurnal Fakultas Hukum Kertha Semaya, 5, No. 5, (2017), 2.

5 Nurcahya G. Ketut, dan Ariana Putra I Gede, "Perlindungan Hukum Terhadap Konsumen Di Indonesia Terkait Bahaya Konsumsi Rokok Elektrik." Jurnal Kertha Semaya, 6, No. 1, (2017), 9.

6 Kresnayana I Made dan Parsa I Wayan, "Perlindungan Hukum Terhadap Konsumen Terkait Cairan Rokok Elektrik Yang Tidak Mencantumkan Tanggal Kadaluarsa." Jurnal Hukum Kertha Semaya, 5, No. 1, (2017), 5. 
elektrik di Indonesia. ${ }^{7}$ Beranjak dari data tersebut dapat disimpulkan bahwa konsumer nikotin cair di Indonesia perlu diberikan perlindungan agar konsumen sadar bahwa produk yang akan dikonsumsi memiliki zat-zat yang berbahaya.

State of The Art penelitian ini mengambil contoh dari penelitian yang telah dilakukan dalam bentuk jurnal yang berjudul "Tanggung Jawab Perusahaan Vapor Juice Inc Bali Terhadap Konsumen Pembeli Rokok Elektrik Jika Terjadi Ledakan Rokok Elektrik" oleh Daniel Alexander Soebroto AM dan Ida Bagus Putu Sutama pada tahun 2013. Dalam penelitian tersebut dijelaskan bagaimana bentuk pertanggung jawaban dari perusahaan Vapor Juice Inc Bali apabila terjadi ledakan terhadap penggunaan rokok elektrik atau vape. ${ }^{8}$ Namun Jurnal tersebut hanya membahas tanggung jawab perusahaan dalam halnya terjadi ledakan, maka dari itu dalam penulisan penelitian ini akan difokuskan terhadap tanggung jawab perusahaan yang mengelola nikotin cair terhadap kemasan yang tidak memiliki peringatan kesehatan karena nikotin cair dinilai sebagai zat yang berbahaya bagi tubuh manusia terlebih lagi belum ada penelitian lebih lanjut mengenai penggunaan dalam jangka panjang.

Dalam hal mendasar juga konsumen belum mendapatkan ha katas perlindungan kesehatan apabila pelaku usaha tidak mencantumkan peringatan kesehatan pada hasil produk nikotin cairnya. Hak konsumen ini termuat dalam Pasal 4 ayat 1 UndangUndang Nomor 8 Tahun 1999 tentang Perlindungan Konsumen (Selanjutnya disebut UUPK), "konsumen memiliki hak atas keselamatan, kenyamanan, dan keamanan dalam mengkonsumsi barang dan atau jasa. Berdasarkan uraian yang telah dijabarkan dilakukan penelitian dengan judul "TANGGUNG JAWAB PELAKU USAHA NIKOTIN CAIR YANG TIDAK TERCANTUM PERINGATAN KESEHATAN PADA KEMASANNYA"

\subsection{Rumusan Masalah}

Beranjak dari latar belakang yang telah diuraikan diatas dapat dirumuskan dua permasalahan penelitian:

1. Bagaimana bentuk perlindungan konsumen nikotin cair yang dalam kemasannya tidak tercantum peringatan kesehatan dan label informasi?

2. Bagaimana akibat hukum yang diterima oleh pelaku usaha nikotin cair atas bahaya yang ditimbulkan akibat tidak mencantumkan peringatan Kesehatan dan label informasi?

\subsection{Tujuan Penelitian}

Penulisan jurnal ilmiah bertujuan mengetahui bentuk perlindungan terhadap konsumen nikotin cair yang tidak tercantum label informasi dan peringatan kesehatan dalam kemasannya serta untuk mengetahui tanggung jawab pelaku usaha atas akibat dari bahaya yang ditimbulkan dari konsumsi nikotin cair tersebut.

7 Angga Ade S. P. dan Surya Dharma Jaya I. B, “Tanggung Jawab Penjual Rokok Elektrik Pada Transaksi Online." Jurnal Hukum Kertha Semaya, 6, No. 1 (2017), 7.

8 Daniel Aleksander Soebroto A.M dan Ida Bagus Putu Sutama, "Tanggung Jawab Perusahaan Vapor Juice Inc Bali Terhadap Konsumen Pembeli Rokok Elektrik Jika Terjadi Ledakan Rokok Elektrik.", Jurnal Hukum Kertha Semaya, 1, No. 11 (2013), 8. 


\section{Metode Penelitian}

Penulisan jurnal ini digunakan jenis penelitian normatif dimana dilakukan pengkajian peraturan perundang-undangan yang berlaku serta menggunakan data sekunder sebagai data utama. Penulisan jurnal ini menggunakan pendekatan perundang-undangan (the statute approach) dengan mengidentifikasi peraturan perundang-undangan yang relevan seperti Undang-Undang Perlindungan Konsumen Nomor 8 Tahun 1999, Undang-undang Nomor 39 Tahun 2009 Tentang Kesehatan, Peraturan Pemerintah Nomor 109 Tahun 2012 Tentang Pengamanan Bahan Yang Mengandung Zat Adiktif Berupa Produk Tembakau Bagi Kesehatan, dan Peraturan Menteri Kesehatan Republik Indonesia Nomor 28 Tahun 2013 tentang Pencantuman Peringatan Kesehatan Dan Informasi Kesehatan Pada Kemasan Produk Tembakau. Data yang telah dikumpulkan kemudian dianalisa menggunakan metode normatif kualitatif dimana data akan disimpulkan dengan tujuan memperoleh gambaran umum mengenai permasalahan.

\section{Hasil Dan Pembahasan}

\subsection{Perlindungan Konsumen Nikotin Cair yang Tidak Tercantum Label Informasi dan Peringatan Kesehatan Pada Kemasannya}

Walaupun banyak hal negatif yang didapatkan dalam kegiatan merokok (seperti kanker, gangguan syaraf, asam lambung, hingga gangguan psikologis) tetap saja masyarakat Indonesia tidak merasa dihantui akan hal tersebut. ${ }^{9}$ Kebiasaan merokok ini dapat menggugah rasa kesenangan sementara bagi penggunanya, tetapi di sisi lain, pihak sekitar pengguna juga dapat terkena dampak buruk dari perokok tersebut. Secara umum perokok dapat dikategorikan menjadi dua jenis (perokok pasif dan perokok aktif), yang dimaksud dengan perokok pasif adalah asap rokok yang dihirup secara tidak langsung oleh orang yang tidak merokok sedangkan perokok aktif adalah asap rokok yang secara langsung dihirup oleh perokok tersebut. ${ }^{10}$

Atas efek kesenangan sementara yang di timbulkan oleh rokok atau nikotin tersebut, muncul ketergantungan atau candu terhadap produk tersebut yang kemudian membuat perokok aktif susah untuk melepaskan kebiasaannya. Seiring perkembang jaman perokok menemukan alternatif lain untuk menikmati nikotin yaitu dengan vape atau vapor. ${ }^{11}$ Untuk dinikmati, produk rokok elektronik harus memiliki 3 komponen penting seperti bagian baterai, bagian atomizer (digunakan untuk menguapkan cairan nikotin) serta bagian nikotin dalam bentuk cairan. ${ }^{2}$ Namun yang tidak diketahui oleh konsumen vape atau rokok elektrik ini adalah baik rokok konvensional (rokok batangan) maupun vape atau rokok elektrik sama-sama memiliki dampak berbahaya bagi kesehatan tubuh mulai dari kanker mulut, kerusakan jaringan mulut, syaraf otak

9 Bahtiar A. dan Edy Rahardja, "Pengaruh Brand Equity, Harga dan Distribusi Terhadap Keputusan Pembelian Vape (Studi Pada Vape Store 5Time)." Dipoenegoro Journal Of Management, 6, No. 4, (2017), 5.

10 Rohmani A. "Rokok Elektrik dan Rokok Konvensional Merusak Alveolus Paru". Jurnal Kedokteran Brawijaya, 21, No. 3, (2016), 12.

11 Marsigit Bimantara, "Vape Sebagai Gaya Hidup Konsumtif Baru Di Masyarakat." Jurnal Phinisi Integration Review Universitas Indonesia, 1, No. 2, (2018), 132.

12 Adhima El Hasna dan Cahyo Kusyogo, "Faktor-Faktor Yang Berhubungan Dengan Penggunaan Rokok Elektrik Pada Perokok Pemula Di Sma Kota Bekasi." Jurnal Nasional Kesehatan Masyarakat (e-Journal), 5, No. 3, (2017), 552. 
hingga gangguan psikologis. ${ }^{13}$ Hal ini menjadi salah satu alasan pentingnya perlindungan terhadap konsumen rokok elektrik atau vape.

Penjelasan mengenai rokok elektronik ini dapat dilihat di Pasal 1 Peraturan Menteri Perdagangan Republik Indonesia Nomor 86 Tahun 2017 Tentang Ketentuan Impor Rokok Elektrik yang menyatakan "Yang dimaksud dengan rokok elektrik adalah perangkat rokok yang digunakan dengan memanaskan cairan yang menghasilkan asap kemudian dihisap oleh penggunanya termasuk di dalamnya Likuid Nikotin (nikotin cair) dan pengganti Likuid Nikotin yang digunakan sebagai aparatus tersebut."

Kemudian mengenai Nikotin Cair atau Likuid Nikotin tersebut menurut Peraturan Menteri Keuangan Republik Indonesia No. 67/PMK.04/2018 Tentang Perdagangan Barang Kena Cukai Yang Pelunasan Cukainya Dengan Cara Pelekatan Pita Cukai Atau Pembubuhan Tanda Pelunasan Cukai Lainnya, termasuk dalam bagian Hasil Pengolahan Tembakau Lainnya (HPTL) yaitu Ekstrak dan Essens Tembakau tercantum dalam Pasal 1 angka 18, "Ekstrak dan Esens Tembakau adalah hasil tembakau dalam bentuk cair, padat, atau bentuk lainnya yang berasal dari pengolahan daun tembakau yang dibuat dengan cara ekstraksi atau cara lain mengikuti perkembangan teknologi serta selera konsumen yang disediakan untuk konsumen akhir dalam bentuk kemasan penjualan eceran kemudian dikonsumsi dengan cara dipanaskan menggunakan alat pemanas elektrik (vape) kemudian dihisap." Dapat disimpulkan nikotin cair tersebut termasuk dalam kategori Produk Tembakau.

Secara yuridis produk yang mengandung zat adiktif diatur dalam Pasal 113 ayat (2) Undang-undang Kesehatan yang menyatakan "Zat adiktif sebagaimana dimaksud pada ayat (1) meliputi produk yang mengandung tembakau, padat, cairan, dan gas yang bersifat adiktif yang penggunaannya dapat menimbulkan kerugian bagi dirinya dan/atau masyarakat sekelilingnya." Secara langsung memberi arti bahwa nikotin cair sebagai bagian dari kegiatan vape adalah produk yang mengandung zat adiktif.

Atas kandungan nikotin di dalam penggunaan vape atau rokok elektrik tersebut, Pasal 114 Undang-undang No. 39 Tahun 2009 Tentang Kesehatan menjadi aturan pembatas terhadap penggunaan, produksi, serta pencantuman peringatan kesehatan pada kemasan zat adiktif nikotin. ${ }^{14}$ Pasal 114 menyatakan "Setiap orang yang memproduksi atau memasukkan rokok ke wilayah Indonesia wajib untuk mencantumkan label peringatan kesehatan."

Hal-hal yang harus dicantumkan berdasarkan Peraturan Pemerintah Nomor 109 Tahun 2012 Tentang Pengamanan Bahan Yang Mengandung Zat Adiktif Berupa Produk Tembakau Bagi Kesehatan, diantaranya:

1. Peringatan kesehatan yang berbentuk tulisan atau lima gambar yang masingmasing berbeda, dengan proporsi masing-masing dua puluh persen dari jumlah setiap varian produk tembakaunya. (tercantum dalam Pasal 15 Peraturan Pemerintah Nomor 109 Tahun 2012) serta wajib mencantumkan paling sedikit 2 jenis gambar dan tulisan peringatan kesehatan yang di tetapkan dalam Peraturan Menteri.

13 CNN Indonesia, Tim. Kemenkes dan BPOM tidak memiliki komentar untuk Aturan Rokok Elektrik. 2019, Retrieved from: https://www.cnnindonesia.com/gayahidup/20191005000718-255-436907/ tak-ada-satu-kata-kemenkes-dan-bpom-untuk-aturanvape

14 Kurniawan Y. A. "Pengenaan Cukai Terhadap Rokok Elektrik Menurut Pasal 2 UndangUndang Nomor 39 Tahun 2007 Tentang Cukai." Jurnal Hukum Universitas Brawijaya, 2, No. 3 , (2018), 14. 
2. Gambar serta tulisan "Peringatan Kesehatan" sebagaimana dimaksud dalam Pasal 15 Peraturan Pemerintah Nomor 109 Tahun 2012 wajib dicantumkan pada setiap kemasan (terkecil maupun terbesar) produk tembakau (tercantum dalam pasal 17 ayat 1), kemudian Pencantuman tulisan dan gambar sebagaimana dimaksud pada ayat (1) wajib memenuhi persyaratan berupa: pencantuman kata "peringatan" dengan huruf berwarna putih yang berdasar hitam, dicetak jelas dan mencolok baik sebagian ataupun seluruhnya pada bagian atas kemasan sisi lebar bagian depan dan belakang, gambar sebagaimana pada huruf "a" harus dicetak berwarna dan, huruf menggunakan "arial bold" dengan font berukuran sepuluh (proposional sesuai kemasan).

Lebih lanjut mengenai pencantuman Informasi Kesehatan dan Label Peringatan diatur dalam Peratura Menteri Kesehatan Republik Indonesia Nomor 28 Tahun 2013 tentang Pencantuman Peringatan Kesehatan dan Informasi Kesehatan Pada Kemasan Produk Tembakau. Keterangan-keterangan tersebut wajib dicantumkan di kemasan rokok.

Selain hak konsumer yang telah diatur dalam Pasal 4 UUPK tersebut, adapun kewajiban bagi pelaku usaha yang diatur pada Pasal 7 huruf b UUPK: memberikan informasi yang benar, jujur, dan jelas atas kondisi barang dan/atau jasa. Kurangnya informasi yang diberikan oleh pelaku usaha dapat dianggap sebagai produk (cacat informasi) yang kemudian memungkinkan konsumen mengalami kerugian. Penyampaian informasi yang benar terhadap gambaran suatu produk tertentu dapat dilakukan dalam bentuk peringatan maupun instruksi. ${ }^{15}$

Beranjak dari hal-hal yang telah dijelaskan di atas, pihak pelaku usaha wajib memberikan informasi yang mudah dibaca dan dipahami oleh konsumer, serta jujur. Dalam hal ini berati pelaku usaha nikotin cair secara wajib memberikan informasi yang jelas mengenai apa saja yang berkaitan dengan rokok elektrik serta kandungan yang diberikan ketika konsumen membeli rokok elektrik. Hal ini yang kemudian menjadi pelengkap hak konsumen serta perlindungan terhadap konsumen sesuai dalam ketentuan UUPK Pasal 4 ayat (1).

\subsection{Tanggung Jawab Pelaku Usaha Akibat dari Bahaya yang Ditimbulkan dari Konsumsi Nikotin Cair}

Bagi pelaku usaha yang telah melakukan pelanggaran ketentuan produk tembakau khususnya nikotin cair, salah satunya dengan tidak mencantumkan peringatan kesehatan secara jelas, sebagaimana yang telah diatur dalam Pasal 14 ayat (1) Peraturan Pemerintah Nomor 109 Tahun 2012 Tentang Pengamanan Bahan Yang Mengandung Zat Adiktif Berupa Produk Tembakau Bagi Kesehatan terhadap produk Rokok Elektronik. Dimana Peringatan kesehatan yang di maksud pada ayat (1) adalah peringatan yang berbentuk gambar dan tulisan yang harus mempunyai satu makna. Maka dalam hal ini dapat diberikan sanksi hukum berupa sanksi adminitratif sesuai ketentuan Pasal 60 ayat (3) berupa: teguran tertulis, teguran lisan, penarikan produk, rekomendasi penghentian sementara kegiatan; dan/atau, rekomendasi penindakan kepada instansi terkait sesuai dengan ketentuan peraturan perundang-undangan

Dalam konteks pertanggung jawaban pelaku usaha, Pasal 18 ayat (1) UUPK hanya mencantumkan bahwa pihak pelaku usaha wajib bertanggung jawab, namun tidak

15 Miru Ahmadi dan Sutarman Yodo, Hukum Perlindungan Konsumen, (Jakarta, Rajawali Pers, 2005), 55 . 
terdapat penjelasan secara eksplisit mengenai pelaku usaha yang dimasud. ${ }^{16}$ Atas dasar kepastian hukum, sudah seharusnya terdapat kejelasan mengenai pelaku usaha yang dibebani tanggung jawab terhadap kerugian yang dialami konsumen nikotin cair. ${ }^{17}$ Selaras dengan ketentuan tersebut, dalam Pasal 8 ayat (1) huruf i UUPK menyatakan: pelaku usaha dilarang memperdagangkan dan/atau memproduksi barang tanpa tercantum label yang memuat penjelasan barang seperti: tanggal produksi (tanggal pembuatan), akibat samping, ukuran, nama barang, berat bersih (netto), alamat pelaku usaha serta keterangan lain. Kemudian dalam Pasal 9 ayat (1) huruf j juga dinyatakan bahwa: "menggunakan kata-kata yang berlebihan, seperti aman, tidak berbahaya, tidak mengandung risiko atau efek sampingan tanpa keterangan yang lengkap;" terkait dengan tidak mencantumkan informasi kesehatan, efek samping secara lengkap. Abainya pelaku usaha terhadap kerugian yang dialami konsumer dapat digugat oleh konsumer melalui badan peradilan sesuai dengan pasal 23 UUPK.

\section{$4 \quad$ Kesimpulan}

Beranjak dari ulasan diatas dapat ditarik dua buah kesimpulan yaitu masih terdapat pelaku usaha rokok elektronik yang tidak mengetahui peraturan mengenai vape khususnya pencantuman informasi Kesehatan dan label informasi yang telah tertera dalam Pasal, 15, Pasal 20, Pasal 21, Pasal 22 Peraturan Pemerintah Nomor 109 Tahun 2012 Tentang Pengamanan Bahan Yang Mengandung Zat Adiktif serta Pasal 113, Pasal 114, dan Pasal 115 Undang-Undang Nomor 36 Tahun 2009 Tentang Kesehatan dan Informasi mengenai zat dalam kemasan rokok elektronik wajib dicantumkan sebagai pemenuhan hak konsumen serta kewajiban pelaku usaha rokok elektronik hal ini dikarenakan rokok elektronik ini dapat dikategorikan sebagai salah satu produk tembakau (produk olahan tembakau). Hal ini yang kemudian menjadi pelengkap hak konsumen serta perlindungan terhadap konsumen sesuai dalam ketentuan UUPK Pasal 4 ayat (1). Hasil produk yang tidak memiliki informasi memadai dapat dikategorikan sebagai produk cacat informasi yang kemudian dapat merugikan konsumen.

Pelaku usaha yang telah melakukan pelanggaran ketentuan produk tembakau, khususnya rokok elektrik dengan tidak mencantumkan peringatan kesehatan secara jelas dapat diberikan sanksi hukum berupa sanksi adminitratif sesuai ketentuan pasal 60 ayat (3) Peraturan Pemerintah Nomor 109 Tahun 2012 tentang Pengamanan Bahan Yang Mengandung Zat Adiktif Berupa Produk Tembakau Bagi Kesehatan terhadap Produk Rokok Elektronik berupa: teguran lisan, teguran tertulis, penarikan produk, rekomendasi penghentian sementara kegiatan, dan/atau rekomendasi penindakan kepada instansi terkait sesuai dengan ketentuan peraturan perundang-undangan. Abainya pelaku usaha terhadap kerugian yang dialami konsumer dapat digugat oleh konsumer melalui badan peradilan sesuai dengan pasal 23 UUPK.

Kemudian saran yang dapat diberikan oleh penulis adalah diberlakukan langkah hukum dari pemerintah sebagai tanggung jawab pemerintah pusat dan lembaga terkait atas keberadaan rokok elektrik dipasar Indonesia. Hal ini untuk melindungi hak-hak konsumen rokok di Indonesia. Yang kedua pemerintah disarankan harus mengadakan kegiatan sosialisasi dan penyuluhan hukum dari pemerintah mengenai rokok elektrik serta memberikan sanksi tegas sebagai penindakan bagi pelaku usaha yang berbuat curang.

$16 \mathrm{Ibid}, 64$.

17 Ibid, 126. 


\section{DAFTAR PUSTAKA}

\section{Buku:}

Celina Tri Siwi K., Hukum Perlindungan Konsumen, (Jakarta, Rajawali Pers, 2011)

Sidharta, Hukum Perlindungan Konsumen Indonesia, (Jakarta, PT. Grafindo, 2000) h. 5

Miru Ahmadi dan Sutarman Yodo, Hukum Perlindungan Konsumen, (Jakarta, Rajawali Pers, 2005).

\section{Jurnal:}

Adhima El Hasna dan Cahyo Kusyogo, "Faktor-Faktor Yang Berhubungan Dengan Penggunaan Rokok Elektrik Pada Perokok Pemula Di Sma Kota Bekasi." Jurnal Kesehatan Masyarakat (e-Journal), 5, No. 3, (2017), 552.

AM, D. A. S, \& Sutama, I. B. P, “Tanggung Jawab Perusahaan Vapor Juice Inc Bali Terhadap Konsumen Pembeli Rokok Elektrik Jika Terjadi Ledakan Rokok Elektrik." Jurnal Fakultas Hukum Kertha Semaya, 5, No. 5, (2017), 2.

Angga Ade S. P. dan Surya Dharma Jaya I. B, “Tanggung Jawab Penjual Rokok Elektrik Pada Transaksi Online." Jurnal Hukum Kertha Semaya, 6, No. 1 (2017), 7.

Bahtiar A. dan Rahardja Edy, "Pengaruh Brand Equity, Harga dan Distribusi Terhadap Keputusan Pembelian Vape (Studi Pada Vape Store 5Time)." Dipoenegoro Journal Of Management, 6, No. 4, (2017), 5.

Desiyana Vernia dan Sarjana I Made, "Perlindungan Konsumen Terhadap Batasan Kandungan Tar Dan Nikotin Pada Produk Rokok." Jurnal Hukum Kertha Semaya, 7, No. 8, (2019), 8.

Hacinka Batan dan Westra I Ketut, "Peredaran Produk Rokok Elektronik Yang Tidak Mencantumkan Label Komposisi Zat Adiktif Dalam Perspektif Hukum Perlindungan Konsumen." Jurnal Hukum Kertha Semaya, 5, No. 1 (2017), 7.

Kurniawan Y. A. "Pengenaan Cukai Terhadap Rokok Elektrik Menurut Pasal 2 UndangUndang Nomor 39 Tahun 2007 Tentang Cukai." Jurnal Hukum Universitas Brawijaya, 2, No. 3, (2018), 14.

Komang I W. dan I Nyoman Mudana, "Pelaksanaan Peraturan Daerah Provinsi Bali Nomor 10 Tahun 2011 Tentang Kawasan Tanpa Rokok Dalam Rangka Perlindungan Terhadap Perokok Pasif." Jurnal Hukum Kertha Negara, 02, No. 01, (2014), 3.

Kresnayana I Made dan Parsa I Wayan, "Perlindungan Hukum Terhadap Konsumen Terkait Cairan Rokok Elektrik Yang Tidak Mencantumkan Tanggal Kadaluarsa." Jurnal Hukum Kertha Semaya, 5, No. 1, (2017), 5.

Marsigit Bimantara, "Vape Sebagai Gaya Hidup Konsumtif Baru Di Masyarakat." Jurnal Phinisi Integration Review Universitas Indonesia, 1, No. 2, (2018), 132.

Nurcahya G. Ketut, dan Ariana Putra I Gede, "Perlindungan Hukum Terhadap Konsumen Di Indonesia Terkait Bahaya Konsumsi Rokok Elektrik." Jurnal Kertha Semaya, 6, No. 1, (2017), 9.

\section{Peraturan Perundang-Undangan}

Undang Undang No. 8 Tahun 1999 Tentang Perlindungan Konsumen (Lembaran Negara Republik Indonesia tahun 1999 No. 42 Tambahan lembaran Negara Republik Indonesia No. 3821.

Undang-Undang Nomor 36 Tahun 2009 tentang Kesehatan (Lembaran Negara Republik Indonesia Tahun 2009 Nomor 144, Tambahan Lembaran Negara Republik Indonesia Nomor 5063). 
Peraturan Pemerintah Nomor 109 Tahun 2012 Tentang Pengamanan Bahan Yang Mengandung Zat Adiktif Berupa Produk Tembakau Bagi Kesehatan

Peraturan Menteri Kesehatan Republik Indonesia Nomor 28 Tahun 2013 tentang Pencantuman Peringatan Kesehatan Dan Informasi Kesehatan Pada Kemasan Produk Tembakau

\section{Internet}

CNN Indonesia, Tim. Tak Ada Satu Kata Kemenkes dan BPOM untuk Aturan Vape. 2019, Retrieved from: https://www.cnnindonesia.com/gayahidup/20191005000718-255-436907/ tak-ada-satu-kata-kemenkes-dan-bpomuntuk-aturan-vape 